\title{
Pure and Decorative Plywood Panels from Cordia trichotoma and Grevillea robusta
}

\author{
Rosilani Trianoski ${ }^{1}$, Setsuo Iwakiri ${ }^{1}$ \\ ${ }^{1}$ Universidade Federal do Paraná - UFPR, Curitiba/PR, Brasil
}

\begin{abstract}
The objective of this study was to evaluate the technical viability of Cordia trichotoma and Grevillea robusta wood for the production of plywood panels, as well as to verify the behavior of these species in combination with Pinus taeda and Eucalyptus saligna. Panels were produced using veneers of each species and in combination, totaling 8 treatments. The panels were glued with urea-formaldehyde using grammage of $180 \mathrm{~g} / \mathrm{m}^{2}$; pressed at a temperature of $110{ }^{\circ} \mathrm{C}$, with pressure of $1 \mathrm{MPa}$ and a pressing time of 8 minutes. The results of the density, moisture content, superficial and total water absorption, static bending and shear tests of the core, face and back-face veneers, indicated the viability of Cordia trichotoma and Grevillea robusta for the production of plywood for interior purposes using all veneers of these species, as well as, in the production of decorative plywood manufactured using Pinus or Eucalyptus veneers.
\end{abstract}

Keywords: planted forests, wooden panels, louro pardo, grevilea. 


\section{INTRODUCTION}

The production and use of plywood panels at an industrial scale dates from the beginning of $20^{\text {th }}$ century in the United States (Baldwin, 1981). From this moment, it became a product widely used in the civil construction and furniture industries due to its greater dimensional stability, superior mechanical resistance distribution and greater yield when compared to solid wood (Iwakiri, 2005).

In Brazil, the plywood industry started activities in the 1940s, being concentrated primarily in southern Brazil. Large-scale use was made of Araucaria angustifolia wood which is derived from the native forests, mainly in Paraná state (Vieira et al., 2012), due to its abundance at that time, and, also due to its excellent characteristics for producing veneers for plywood manufacture (Bonduelle et al., 2006).

Due to agricultural expansion and excessive wood extraction in southern Brazil during the 1960s, this industry moved to the Amazon region, where it began to use hardwoods obtained from the native forests (Vieira et al., 2012). Up to 1998, this was the main supply source for plywood production (ABIMCI, 2008 ), representing $70 \%$ of the raw material used for this purpose (Zugman, 1998).

However, factors such as harvesting costs, the long distances when transporting the logs, veneers or manufactured plywood to the principal consumption centers, and pressure from environmental groups regarding the origin of the wood and the necessary certification, led to tropical plywood becoming more restricted, generating a need to substitute tropical wood with wood derived from plantations (Bortoletto, 2003). In addition to these factors, the significant quantity of wood coming from planted Pinus forests, stimulated by tax incentive in the 60 s, ended up attracting many companies back to southern Brazil (ABIMCI, 2005).

Thus, from 1999, with these changes in the forestry industry, Pinus plantations became an important source of raw materials for the plywood industry, where the production began to use around $60 \%$ wood from planted forests and $40 \%$ from native forests. This tendency persisted over the years and, in 2012 it was observed that plywood manufactured using wood from planted forests was approximately $81 \%$, against $19 \%$ harvested from native tropical forests (ABIMCI, 2013).
This drop in production of tropical plywood over recent years, in addition to the previously mentioned factors, occurred due to the difficulty in obtaining quality raw materials of legal origin, as well as, the intensification in monitoring of wood extraction from forests and competition from Chinese producers (ABIMCI, 2013). Finally, the price of tropical plywood is, on average, 60\% higher than Pinus plywood (Vieira et al., 2012; ABIMCI, 2013).

The aesthetic preference of the consumer is one of the factors that influences purchasing decisions for tropical plywood. Normally, tropical plywood presents an attractive veneer with differentiated colors and forms, not requiring application of covering films such as melamine paper on MDP and MDF panels.

Therefore, to meet this demand, it is necessary to stimulate the planting of native and exotic species that possess wood with these characteristics, so that they can serve as raw material for the plywood industry. As an example, the study of Trianoski et al., (2015) can be cited, who, when evaluating Melia azedarach wood concluded that this specie shows technical viability for plywood panels production, and its good quality, beautiful aesthetic and decorative aspects can be a deciding factor for application of this product in the furniture industry. Additionally, there are other native or exotic species with wood presenting good aesthetic characteristics and fine drawing, with Cordia trichotoma and Grevillea Robusta being notable in this regard.

Cordia trichotoma is a native species that belongs to the Boraginaceae family, popularly known as Louro pardo. It is promising for plantations with commercial aims, presenting a combination of favorable aspects, with its good stem form and high quality wood being notable (Carvalho, 2006). It possesses moderately heavy, hard, easily workable wood, that is highly attractive and widely used in the manufacture of furniture, decorative coverings, doors, windows, frames and large barrels. When used in carpentry it can provide valuable parts, as well as in sculpture and for the construction of boats. Large scale applications in interiors and in the structure itself present other important uses (Lorenzi, 1998). In Brazil, the species has been tested in different agroforestry system modalities, also being found regularly in the provincial mountain ranges in the States of Ceará, Paraíba and Pernambuco. Its wider dispersion area is extends from the Atlantic Pluvial Tropical Forest to the Pluvial Subtropical Forest. In the South, Center-West 
and Southeast of Brazil, the louro-pardo is one of the most promising native species for plantation (Carvalho, 1988), where small experimental plantations in the region of Corupá - SC were observed.

Grevillea robusta, known popularly as Grevilea, belongs to the Proteaceae Family, and is native to Australia, being found in tropical and subtropical regions of the Southern Hemisphere (Inoue \& Martins, 2006). It was introduced into Brazil at the end of $19^{\text {th }}$ century, in the state of São Paulo, with the objective of providing shade in coffee plantations, subsequently being recommended to form windbreaks in these same plantations (Martins et al., 2004). Currently, it has been observed in small plantations in the States of Paraná, Rio Grande do Sul, Mato Grosso and Santa Catarina. It is considered a fast growing species that demonstrates good adaptation and production for commercial use (Inoue \& Martins, 2006). Canto \& Schneider (2004) emphasize its excellent growth and potential for plantations with the objective of manufacturing large sized timber for sawing or even lamination, as its wood presents good technological characteristics. Lamprecht (1990) describes the wood as highly attractive, with beautiful drawings, especially around the knots, and Inoue \& Martins (2006) emphasize its application in decorative panels due to its natural brightness.

In addition to planting native or exotic species, another way of generating plywood with the desired aesthetic characteristics is to produce panels with a combination of species (type "combi"), mainly species traditionally used for this purpose, such as Pinus and Eucalyptus. Using veneers of more available, less expensive species in the internal layer or in the core of the panel, and decorative veneers on the face and backing, frequently provides a cost reduction for the end product without a reduction in quality.

In this context, this study aimed to evaluate the technical viability of Cordia trichotoma and Grevillea robusta veneers for plywood panel production, as well as to check the behavior of these species in combination with Pinus and Eucalyptus veneers.

\section{MATERIAL AND METHODS}

For the development of this research Cordia trichotoma, Grevilea robusta, Eucalyptus saligna and Pinus taeda species were used. The Cordia trichotoma and Grevilea robusta species were obtained from 19-year-old experimental plantations, located in the region of Corupá - SC (26 $23^{\prime} 19,32^{\prime \prime}, 49^{\circ} 16^{\prime} 50,74^{\prime \prime} \mathrm{S}$ and $75 \mathrm{~m}$ altitude), belonging to Batistella Florestal. The region's climate is subtropical, with an average temperature between $15^{\circ} \mathrm{C}$ and $25^{\circ} \mathrm{C}$, ranging between $0{ }^{\circ} \mathrm{C}$ and $35{ }^{\circ} \mathrm{C}$. Annual average precipitation varies from 1200 to 1600 $\mathrm{mm}$, and periodic frosts occur throughout the year. The Eucalyptus saligna and Pinus taeda wood came from 18-year-old plantations, belonging to Valor Florestal, located in the region of Ventania - PR $\left(24^{\circ} 14^{\prime} 45^{\prime \prime} \mathrm{S}\right.$, $50^{\circ} 14^{\prime} 34^{\prime \prime} \mathrm{W}$, and 990 meters altitude), where the climate is subtropical humid mesothermic, average annual precipitation is approximately $1400 \mathrm{~mm}$ and frequent, severe frosts occur.

In both plantations, the trees of each species were selected using the sampling recommended by the COPANT (1972a) norms, wherein the dendrometrical characteristics obtained were: Grevilea robusta: diameter at breast height (DBH): $21.52 \mathrm{~cm}$, commercial height (Ch): $7.92 \mathrm{~m}$, total height (Th): $13.78 \mathrm{~m}$; Cordia trichotoma: DBH: $22.28 \mathrm{~cm}$, Ch: 10.78 m, Th: 16.04 m; Pinus taeda: DBH: $33.95 \mathrm{~cm}$, Ch: $16.25 \mathrm{~m}$, Th:18.50 m; and Eucalyptus saligna: DBH: $33.10 \mathrm{~cm}$, Ch: $30.70 \mathrm{~m}$, Th: $36.92 \mathrm{~m}$. The volume was calculated using the Smalian equation according to the recommendations of Machado \& Figueiredo (2006).

After felling, the trees were sectioned in accordance with the commercial height, obtaining samples at positions relative to $0,25,50,75$ and $100 \%$ of the stem for density evaluation, which was determined according to the COPANT (1972b) standard, and logs in these intervals. The logs were submitted to the lamination process without heating, obtaining veneers with nominal thickness of $2 \mathrm{~mm}$, which were dried (6\%-8\%) and sectioned with final dimensions of 500 X $500 \mathrm{~mm}$.

For the production of the plywood panels, urea formaldehyde resin (UF) was used, with solid content of $62 \%$, Brookfield viscosity of $868 \mathrm{cP}$ and $\mathrm{pH}$ of 7,9. The adhesive was formulated from 100 parts per weight of (UF) resin, 20 parts flour, 20 parts water and 1.5 parts catalyzer, generating $42 \%$ solid content of the glue beat. Panels with nominal thickness of $10 \mathrm{~mm}$ (5 veneers) and grammage of $180 \mathrm{~g} / \mathrm{m}^{2}$ (single line) were produced, which were pressed with a specific pressure of $1 \mathrm{MPa}$, temperature of $110^{\circ} \mathrm{C}$ and pressing time of 8 minutes 
in a hydraulic Siempelkamp press, following the design presented in Table 1, with 3 repetitions per treatment.

After pressing and acclimatization $\left(20 \pm 2{ }^{\circ} \mathrm{C}\right.$ and $65 \pm 5 \%$ ), the panels were sectioned to obtain specimens for the evaluation of the physical and mechanical properties regarding: density (EN, 2002b); moisture content (EN, 2002a); superficial and total water absorption (ABNT, 1986); static bending (CEN, 2002a); and shear of the glue line (CEN, 2002b, 2004). The main stages of the experimental design are presented in Figure 1.

The results were submitted for statistical analysis through the Grubbs, Shapiro Wilks, Bartlett tests and Variance analysis. After rejecting the null hypothesis, Tukey's Test was applied. All the tests were executed

Table 1. Experimental chart.

\begin{tabular}{ccc|} 
Treatment & Species & $\begin{array}{c}\text { Composition of } \\
\text { veneers }\end{array}$ \\
\hline 1 & Grevilea robusta & GGGGG \\
2 & Cordia trichotoma & CCCCC \\
\hline 3 & Pinus taeda & PPPPP \\
4 & $\begin{array}{c}\text { Eucalyptus saligna } \\
\text { Grevilea robusta / } \\
\text { Pinus taeda }\end{array}$ & EEEEE \\
\hline 5 & GPPPG \\
\hline 6 & $\begin{array}{r}\text { Cordia trichotoma / } \\
\text { Pinus taeda }\end{array}$ & CPPPC \\
\hline & $\begin{array}{c}\text { Grevilea robusta / } \\
\text { Eucalyptus saligna } \\
\text { Cordia trichotoma / } \\
\text { Eucalyptus saligna }\end{array}$ & GEEEG \\
\hline
\end{tabular}

using the Software Statgraphics Centurion XVI, with $95 \%$ reliability.

\section{RESULTS}

\subsection{Wood properties}

Table 2 presents the average debarked log volume results by species, together with wood density.

The Eucalyptus saligna presented the greatest average volume per tree, possibly indicating greater yield in lamination. On the other hand, G. robusta presented the lowest volume, followed by $C$. trichotoma, showing that, given this and because of the aesthetic characteristics of the wood, they required optimization.

In accordance with Tsoumis (1991), the tree stem diameter and shape present a direct relation to the yield in lamination. Species with high levels of growth and productivity, such as Eucalyptus, are conducive to laminate production in yield terms, but the quality of the veneers can be compromised due to the high growth tensions, requiring minimal storage time between the felling of the tree and lamination, in order to minimize the end splitting.

In terms of wood density, analysis of variance indicated significant statistical differences between the species studied, with E. saligna presenting the highest value, while $P$. taeda presented the lowest wood density, which was statistically inferior to C. trichotoma.

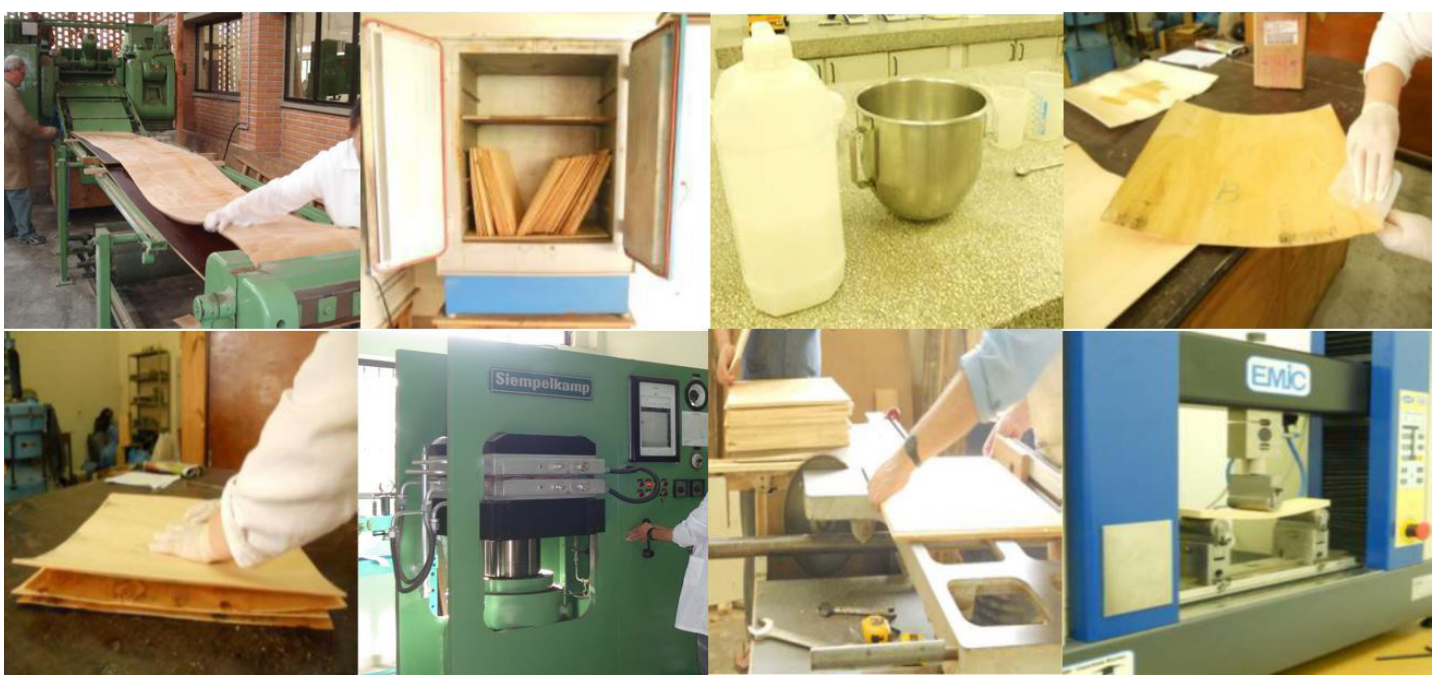

Figure 1. Stages of the manufacture and assessment of the plywood panels. 
No statistically significant difference was observed between the two main target species of this study.

Considering this property, it was noticeable that all species presented average values that classify them as wood with low and medium wood density according to Melo et al. (1990), who suggests values up to $500 \mathrm{~kg} / \mathrm{m}^{3}$ and from 510 to $720 \mathrm{~kg} / \mathrm{m}^{3}$, respectively. This result indicates that all the species are suitable for lamination and consequently for manufacture of plywood panels according to Tsoumis (1991). Additionally, it corroborates information presented by Walker (1993), who argues that species adjusted for manufacture of laminates

Table 2. Average values of debarked log volume and wood density.

\begin{tabular}{ccc|} 
Species & $\begin{array}{c}\text { Volume } \\
\left(\mathbf{m}^{3}\right)\end{array}$ & $\begin{array}{c}\text { Wood density } \\
\left(\mathbf{g} / \mathbf{c m}^{3}\right)\end{array}$ \\
\hline Grevillea robusta & 0.133 & $\begin{array}{c}0.494 \mathrm{bc} \\
(5.62)\end{array}$ \\
Cordia trichotoma & 0.322 & $\begin{array}{c}0.546 \mathrm{~b} \\
(6.31)\end{array}$ \\
Pinus taeda & 0.600 & $\begin{array}{c}0.485 \mathrm{c} \\
(6.08)\end{array}$ \\
Eucalyptus saligna & 2.277 & $\begin{array}{c}0.630 \mathrm{a} \\
(4.99)\end{array}$ \\
\hline
\end{tabular}

Means followed by the same letter in the same column do not differ statistically from one another by Tukey test at $5 \%$ error probability; Values in parentheses refer to the coefficient of variation in percentage. should possess wood density between $380 \mathrm{~kg} / \mathrm{m}^{3}$ and $700 \mathrm{~kg} / \mathrm{m}^{3}$, with a preference for those with $500 \mathrm{~kg} / \mathrm{m}^{3}$.

\subsection{Physical properties of the panels}

Table 3 presents the average values of the panel density properties, moisture content and superficial and total water absorption of the different treatments.

Analysis of variance indicated significant statistical differences in panel density between the different treatments, where the treatment composed exclusively by $E$. saligna veneers presented the highest average value, being statistically superior to the others. The panels that also included E. saligna veneers in their composition, reflected the characteristic of this species in terms of its wood density, tending to increase the density of the final product, with (GEEEG and CEEEC), being statistically different between themselves and superior to the others. On the other hand, panels exclusively manufactured with C. trichotoma, G. robusta and P. taeda, and their different combinations, presented the lowest average values, appearing as statistically equal between themselves.

Generally, the use of veneers of species with greater wood density resulted in panels with greater density, demonstrating the direct relationship between these variables. Panels with greater density normally

Table 3. Average results of physical properties of plywood panels.

\begin{tabular}{|c|c|c|c|c|}
\hline \multirow{2}{*}{ Treatment } & PD & MC & $\mathrm{WA}_{\text {superficial }}$ & $\mathbf{W A}_{\text {total }}$ \\
\hline & $\left(\mathrm{g} / \mathrm{cm}^{3}\right)$ & (\%) & $(\%)$ & $(\%)$ \\
\hline $\begin{array}{c}\text { Grevillea robusta } \\
\text { GGGGG }\end{array}$ & $\begin{array}{c}0.629 \mathrm{~d} \\
(1.49)\end{array}$ & $\begin{array}{c}11.16 \mathrm{~b} \\
(1.35)\end{array}$ & $\begin{array}{c}26.82 \mathrm{~d} \\
(9.70)\end{array}$ & $\begin{array}{c}30.75 \mathrm{~cd} \\
(4.42)\end{array}$ \\
\hline $\begin{array}{l}\text { Cordia trichotoma } \\
\text { CCCCC }\end{array}$ & $\begin{array}{c}0.602 \mathrm{~d} \\
(8.06)\end{array}$ & $\begin{array}{c}11.02 \mathrm{~b} \\
(1.35)\end{array}$ & $\begin{array}{c}36.51 \mathrm{~b} \\
(2.11)\end{array}$ & $\begin{array}{c}38.50 \mathrm{~b} \\
(3.26)\end{array}$ \\
\hline $\begin{array}{l}\text { Pinus taeda } \\
\text { PPPPP }\end{array}$ & $\begin{array}{c}0.597 \mathrm{~d} \\
(5.07)\end{array}$ & $\begin{array}{c}11.51 \mathrm{a} \\
(2.27)\end{array}$ & $\begin{array}{c}40.91 \mathrm{a} \\
(3.72)\end{array}$ & $\begin{array}{c}42.06 \mathrm{a} \\
(1.89)\end{array}$ \\
\hline $\begin{array}{l}\text { Eucalyptus saligna } \\
\text { EEEEE }\end{array}$ & $\begin{array}{c}0.813 \mathrm{a} \\
(1.46)\end{array}$ & $\begin{array}{l}10.54 \mathrm{c} \\
(0.90)\end{array}$ & $\begin{array}{c}25.66 \mathrm{~d} \\
(7.87)\end{array}$ & $\begin{array}{l}27.03 \mathrm{e} \\
(5.72)\end{array}$ \\
\hline $\begin{array}{l}\text { Grevillea robusta and Pinus taeda } \\
\text { GPPPG }\end{array}$ & $\begin{array}{c}0.603 \mathrm{~d} \\
(8.17)\end{array}$ & $\begin{array}{l}11.22 \mathrm{~b} \\
(2.32)\end{array}$ & $\begin{array}{l}38.26 \mathrm{ab} \\
(2.35)\end{array}$ & $\begin{array}{c}39.45 \mathrm{~b} \\
(1.42)\end{array}$ \\
\hline $\begin{array}{l}\text { Cordia trichotoma and Pinus taeda } \\
\text { CPPPC }\end{array}$ & $\begin{array}{l}0.651 \mathrm{~d} \\
(5.83)\end{array}$ & $\begin{array}{c}11.68 \mathrm{a} \\
(1.09)\end{array}$ & $\begin{array}{l}38.17 \mathrm{ab} \\
(1.83)\end{array}$ & $\begin{array}{l}39.91 \mathrm{~b} \\
(2.52)\end{array}$ \\
\hline $\begin{array}{l}\text { Grevillea robusta and Eucalyptus saligna } \\
\text { GEEEG }\end{array}$ & $\begin{array}{c}0.732 \mathrm{~b} \\
(3.19)\end{array}$ & $\begin{array}{c}10.74 \mathrm{c} \\
(0.93)\end{array}$ & $\begin{array}{l}26.06 \mathrm{~d} \\
(16.95)\end{array}$ & $\begin{array}{c}29.59 \mathrm{~d} \\
(4.73)\end{array}$ \\
\hline $\begin{array}{l}\text { Cordia trichotoma and Eucalyptus saligna } \\
\text { CEEEC }\end{array}$ & $\begin{array}{l}0.690 \mathrm{c} \\
(4.08)\end{array}$ & $\begin{array}{c}10.74 \mathrm{c} \\
(1.43)\end{array}$ & $\begin{array}{c}30.95 \mathrm{c} \\
(5.29)\end{array}$ & $\begin{array}{l}32.02 \mathrm{c} \\
(3.94)\end{array}$ \\
\hline
\end{tabular}

PD: Panel density; MC: Moisture content; WA: Water absorption; Means followed by the same letter in the same column do not differ statistically from one another by Tukey test at $5 \%$ error probability; Values in parentheses refer to the coefficient of variation in percentage. 
result in products with greater mechanical strength, especially in terms of static bending. In comparison with the density results presented in the Catalog for Pinus plywood and tropical wood (ABIMCI, 2002a,b), where values ranged between 476 the $641 \mathrm{~kg} / \mathrm{m}^{3}$ and from 520 the $693 \mathrm{~kg} / \mathrm{m}^{3}$, respectively, it was found that the majority of the treatments presented results compatible with the commercially produced panels.

The moisture content of the panels varied from 10.54 to $11.68 \%$, showing significant statistical differences between treatments. However, the differences between the minimum and maximum averages were small. It was observed that the panels produced totally or partially with $E$. saligna veneers presented the lowest average values, being statistically equal between themselves, and, possibly, indicating the influence of the species. The low moisture content presented by the panels after the acclimatization process when compared with the wood itself is explained by the high temperatures applied during pressing, which promotes moisture loss and rearrangement of the hygroscopic regions of the wood, leaving the panel less sensitive to humidity ( $\mathrm{Wu}$, 1999). This information can also be corroborated by Stamm \& Loughborough (1935), who affirm that after the first drying condition or exposure to temperature, the moisture content of rehydrated wood will never be equal to initial levels.

In relation to the average values of the commercial panels, where moisture content varies from 9 to $12 \%$ for Pinus plywoods and from 8 to $11 \%$ for tropical plywoods, it was found that the values were similar, as well as the tendency of tropical plywood to present slightly lower moisture content range variation than Pinus plywood, highlighting the influence of the wood density and its chemical composition.

For the properties of superficial and total water absorption, it was found that the treatments fully or partially produced with Pinus laminates presented the highest average values, in the majority of cases statistically superior to the others. On the other hand, Eucalyptus panels presented the lowest values, which may be explained by the differences in the specific mass and permeability of these species. According to Siau (1984), permeability indicates the ease with which fluid is transferred through a porous solid under the influence of a humidity gradient. Thus, the more porous, that is, the larger the size, number and distribution of the pores in the wood, the lower its specific mass and the greater its permeability, which directly affects ease of water absorption and withdrawal.

\subsection{Mechanical properties of the panels}

Table 4 presents the average values of the modulus of rupture and elasticity in parallel and perpendicular static bending tests.

The results of the static bending test in the parallel direction indicated that the panels produced with $100 \%$ C. trichotoma veneers presented the greatest modulus of rupture, being statistically equal to the treatment exclusively composed of E. saligna. In relation to the modulus of elasticity in the parallel direction, E. saligna produced panels with the greatest rigidity, being statistically superior to all the other treatments. In the perpendicular direction, it was observed that the treatment comprised of $C$. trichotoma veneers on the face and back-face and Pinus in the core were the most resistant, being statistically equal to the treatments produced with $100 \%$ C. trichotoma, P. taeda and E. saligna. For the modulus of elasticity, the treatments produced exclusively with $E$. saligna, in combination with Cordia and Grevillea, and from the combination of Cordia and Pinus presented the best rigidity values, being statistically equal between themselves. On the other hand, the G. robusta panels presented the lowest performance in the cited properties.

Generally, treatments using plywood panels that present greater density values showed the best modulus of rupture and elasticity results. Beyond the direct relation between the plywood density and the density of the wood used in its composition, other factors, such as the chemical and anatomical properties of the wood from different species can influence the quality of the veneer bonding and, consequently, the mechanical strength of the panel.

The average values for the modulus of rupture and elasticity in the parallel and perpendicular directions obtained for the plywood panels produced in this study, are close to the average values of the Pinus plywoods presented in the Technical Catalog of the Abimci (ABIMCI, 2002a,b), which are respectively: 45,36 MPa and 5.139,78 MPa; and 32,05 and 2.590,96 MPa; and the tropical wood values are 49,20 MPa and 5.716,20 MPa; and 46,58MPa and 4.489,59 MPa. 
Table 5 presents the average shear strength values, in the tests of the core, face and back-face of the panels, under the different daily pre-treatments.

In the assessment of the quality of the core gluing or internal glue lines of the panels under dry conditions, it was found that the treatment produced with E. saligna presented the greatest average strength, being statistically equal to the panels produced with $C$. trichotoma and from the combination of C. trichotoma and P. taeda. Under humid conditions, C. trichotoma was superior to all other treatments, with the exception of the treatment produced with E. saligna. No determined tendency for increase or reduction in the results of this property was observed, either under dry conditions

Table 4. Average results of modulus of rupture and elasticity to static bending.

\begin{tabular}{|c|c|c|c|c|}
\hline \multirow[b]{2}{*}{ Treatment } & \multicolumn{2}{|c|}{ Parallel } & \multicolumn{2}{|c|}{ Perpendicular } \\
\hline & $\begin{array}{l}\text { MOR } \\
(\mathrm{MPa})\end{array}$ & $\begin{array}{l}\text { MOE } \\
(\mathrm{MPa})\end{array}$ & $\begin{array}{l}\text { MOR } \\
\text { (MPa) }\end{array}$ & $\begin{array}{l}\text { MOE } \\
(\mathrm{MPa})\end{array}$ \\
\hline $\begin{array}{l}\text { Grevillea robusta } \\
\text { GGGGG }\end{array}$ & $\begin{array}{l}49.86 \mathrm{~cd} \\
(5.77)\end{array}$ & $\begin{array}{l}4466.15 \mathrm{de} \\
(10.75)\end{array}$ & $\begin{array}{l}27.85 \mathrm{~d} \\
(13.40)\end{array}$ & $\begin{array}{c}1700.16 \mathrm{~d} \\
(6.97)\end{array}$ \\
\hline $\begin{array}{l}\text { Cordia trichotoma } \\
\text { CCCCC }\end{array}$ & $\begin{array}{l}76.16 \mathrm{a} \\
(10.13)\end{array}$ & $\begin{array}{c}8285.07 \mathrm{~b} \\
(6.85)\end{array}$ & $\begin{array}{c}40.59 \mathrm{ab} \\
(8.85)\end{array}$ & $\begin{array}{c}2616.74 \mathrm{~b} \\
(6.25)\end{array}$ \\
\hline $\begin{array}{l}\text { Pinus taeda } \\
\text { PPPPP }\end{array}$ & $\begin{array}{l}47.89 \mathrm{~d} \\
(15.16)\end{array}$ & $\begin{array}{l}3990.70 \mathrm{e} \\
(9.17)\end{array}$ & $\begin{array}{l}34.11 \mathrm{abcd} \\
(16.75)\end{array}$ & $\begin{array}{l}1.874 .77 \mathrm{~cd} \\
\quad(7.54)\end{array}$ \\
\hline $\begin{array}{l}\text { Eucalyptus saligna } \\
\text { EEEEE }\end{array}$ & $\begin{array}{c}69.21 \mathrm{ab} \\
(13.45)\end{array}$ & $\begin{array}{c}11788.40 \mathrm{a} \\
(5.66)\end{array}$ & $\begin{array}{c}40.02 \mathrm{ab} \\
(18.77)\end{array}$ & $\begin{array}{c}3829.99 \mathrm{a} \\
(4.78)\end{array}$ \\
\hline $\begin{array}{l}\text { Grevillea robusta and Pinus taeda } \\
\text { GPPPG }\end{array}$ & $\begin{array}{l}49.81 \mathrm{~cd} \\
(13.78)\end{array}$ & $\begin{array}{l}4585.69 \mathrm{de} \\
\quad(9.35)\end{array}$ & $\begin{array}{l}32.37 \mathrm{bcd} \\
(18.98)\end{array}$ & $\begin{array}{c}2372.59 \mathrm{bc} \\
(17.01)\end{array}$ \\
\hline $\begin{array}{l}\text { Cordia trichotoma and Pinus taeda } \\
\text { CPPPC }\end{array}$ & $\begin{array}{l}58.70 \mathrm{bcd} \\
(19.29)\end{array}$ & $\begin{array}{l}6910.69 \mathrm{c} \\
(12.79)\end{array}$ & $\begin{array}{l}42.42 \mathrm{a} \\
(14.77)\end{array}$ & $\begin{array}{c}3745.88 \mathrm{a} \\
(14.20)\end{array}$ \\
\hline $\begin{array}{l}\text { Grevillea robusta and Eucalyptus saligna } \\
\text { GEEEG }\end{array}$ & $\begin{array}{l}55.38 \mathrm{~cd} \\
(8.54)\end{array}$ & $\begin{array}{l}4945.60 \mathrm{~d} \\
(13.30)\end{array}$ & $\begin{array}{l}32.94 \mathrm{bcd} \\
(10.34)\end{array}$ & $\begin{array}{c}4165.78 \mathrm{a} \\
(6.33)\end{array}$ \\
\hline $\begin{array}{l}\text { Cordia trichotoma and Eucalyptus saligna } \\
\text { CEEEC }\end{array}$ & $\begin{array}{l}61.19 \mathrm{bc} \\
(11.10)\end{array}$ & $\begin{array}{l}7548.45 \mathrm{bc} \\
(6.29)\end{array}$ & $\begin{array}{l}30.97 \mathrm{~cd} \\
(21.04)\end{array}$ & $\begin{array}{c}3854.18 \mathrm{a} \\
(6.31)\end{array}$ \\
\hline
\end{tabular}

MOR: Modulus of rupture; MOE: Modulus of elasticity; Means followed by the same letter in the same column do not differ statistically from one another by Tukey test at $5 \%$ error probability; Values in parentheses refer to the coefficient of variation in percentage.

Table 5. Average results of the glue line shear strength.

\begin{tabular}{|c|c|c|c|c|}
\hline \multirow[b]{2}{*}{ Treatment } & \multicolumn{2}{|c|}{ Core } & \multicolumn{2}{|c|}{ Face and back-face } \\
\hline & $\begin{array}{c}\text { Dry } \\
(\mathrm{MPa})\end{array}$ & $\begin{array}{l}\text { Cold water } \\
\text { (MPa) }\end{array}$ & $\begin{array}{c}\text { Dry } \\
(\mathrm{MPa})\end{array}$ & $\begin{array}{l}\text { Cold water } \\
(\mathrm{MPa})\end{array}$ \\
\hline $\begin{array}{c}\text { Grevillea robusta } \\
\text { GGGGG }\end{array}$ & $\begin{array}{l}1.44 b^{16} \\
(12.74)\end{array}$ & $\begin{array}{l}1.15 \mathrm{bc}^{7} \\
(15.04)\end{array}$ & $\begin{array}{l}1.80 \mathrm{~b}^{19} \\
(18.98)\end{array}$ & $\begin{array}{l}1.24 \mathrm{~b}^{8} \\
(29.84)\end{array}$ \\
\hline $\begin{array}{l}\text { Cordia trichotoma } \\
\text { CCCCC }\end{array}$ & $\begin{array}{c}1.60 \mathrm{ab}^{12} \\
(9.01)\end{array}$ & $\begin{array}{l}1.56 \mathrm{a}^{7} \\
(10.50)\end{array}$ & $\begin{array}{l}2.52 \mathrm{a}^{34} \\
(20.58)\end{array}$ & $\begin{array}{l}2.03 \mathrm{a}^{7} \\
(17.29)\end{array}$ \\
\hline $\begin{array}{l}\text { Pinus taeda } \\
\text { PPPPP }\end{array}$ & $\begin{array}{l}1.40 \mathrm{~b}^{9} \\
(15.40)\end{array}$ & $\begin{array}{c}0.99 \mathrm{~cd}^{11} \\
(12.01)\end{array}$ & $\begin{array}{c}2.25 \mathrm{ab}^{29} \\
(9.41)\end{array}$ & $\begin{array}{l}1.04 \mathrm{~b}^{10} \\
(14.70)\end{array}$ \\
\hline $\begin{array}{c}\text { Eucalyptus saligna } \\
\text { EEEEE }\end{array}$ & $\begin{array}{c}1.87 \mathrm{a}^{44} \\
(6.53)\end{array}$ & $\begin{array}{c}1.35 \mathrm{ab}^{28} \\
(11.31)\end{array}$ & $\begin{array}{l}1.22 \mathrm{c}^{26} \\
(24.96)\end{array}$ & $\begin{array}{l}0.56 c^{8} \\
(45.12)\end{array}$ \\
\hline $\begin{array}{l}\text { Grevillea robusta and Pinus taeda } \\
\text { GPPPG }\end{array}$ & $\begin{array}{l}1.43 \mathrm{~b}^{8} \\
(16.52)\end{array}$ & $\begin{array}{l}0.99 \mathrm{~cd}^{10} \\
(12.01)\end{array}$ & $\begin{array}{l}1.76 b^{21} \\
(16.96)\end{array}$ & $\begin{array}{l}0.93 \mathrm{bc}^{6} \\
(27.73)\end{array}$ \\
\hline $\begin{array}{l}\text { Cordia trichotoma and Pinus taeda } \\
\text { CPPPC }\end{array}$ & $\begin{array}{l}1.79 \mathrm{a}^{34} \\
(8.80)\end{array}$ & $\begin{array}{l}1.14 \mathrm{bcd}^{24} \\
(16.12)\end{array}$ & $\begin{array}{c}2.09 \mathrm{ab}^{13} \\
(21.93)\end{array}$ & $\begin{array}{l}1.14 b^{15} \\
(34.03)\end{array}$ \\
\hline $\begin{array}{l}\text { Grevillea robusta and Eucalyptus saligna } \\
\text { GEEEG }\end{array}$ & $\begin{array}{l}1.45 b^{74} \\
(21.56)\end{array}$ & $\begin{array}{l}1.02 \mathrm{~cd}^{52} \\
(24.45)\end{array}$ & $\begin{array}{c}2.12 \mathrm{ab}^{43} \\
(9.83)\end{array}$ & $\begin{array}{l}1.22 \mathrm{~b}^{29} \\
(19.27)\end{array}$ \\
\hline $\begin{array}{l}\text { Cordia trichotoma and Eucalyptus saligna } \\
\text { CEEEC }\end{array}$ & $\begin{array}{l}1.46 b^{44} \\
(17.86)\end{array}$ & $\begin{array}{l}0.92 \mathrm{~cd}^{50} \\
(26.36)\end{array}$ & $\begin{array}{c}2.04 \mathrm{ab}^{61} \\
(22.03)\end{array}$ & $\begin{array}{l}1.11 \mathrm{~b}^{18} \\
(40.73)\end{array}$ \\
\hline
\end{tabular}

Means followed by the same letter in the same column do not differ statistically from one another by Tukey test at $5 \%$ error probability; Overlapped values indicate the percentage of wood failure; Values in parentheses refer to the coefficient of variation in percentage. 
or after immersion in cold water. With the exception of the treatments produced with $100 \%$ Pinus veneers, and combinations of Grevillea and Pinus, Cordia and Eucalyptus, all the others met the minimum requirement of $1 \mathrm{MPa}$, as established by the standard EN 314 (CEN, 2002b, 2004).

Regarding the face and back-face test, whose purpose was to determine the face of gluing between different species, it was found that under dry conditions, C. trichotoma presented the best shear strength. However, it differed only from the treatments produced exclusively with $G$. robusta, E. saligna and from the combination between Grevillea and Pinus. The lowest average values were obtained from the panels produced exclusively with E. saligna, which is statistically inferior in relation to the others.

In the tests after treatment in cold water, similar behavior was observed, where $C$. trichotoma also showed the best gluing quality, being statistically superior to all the other treatments, and E. saligna presented the lowest performance. The other treatments were statistically equal between themselves.

Regarding the low performance presented by the E. saligna panels, it is believed that in

this species, extreme absorption took place at the beginning of the pressing, generating a starving glue line, which in association with other factors, such as the veneer's superficial quality, resulted in low strength. Additionally, it was found that the panels generated with the combination of Grevillea and Pinus produced a poor interaction, which could be associated with the differences in the veneer's finish, which led to poor contact and gluing.

With the exception of the treatments produced with $100 \%$ E. saligna veneers, and from the combination between G. robusta and P. taeda, all the other treatments achieved the minimum requirement of $1 \mathrm{MPa}$ in the face and face-cover test, which made them certified products or combinations. Generally, in order to improve the gluing quality in specific treatments, which did not meet the minimum requirement, alterations in the adhesive formulation are suggested with the intention of increasing shear strength.

Based on the hypothesis proposed, within the productive parameters established in the experimental design, as well as in the results obtained, the species C. trichotoma and G. robusta showed potential for the production of pure, mixed or decorative plywood destined for the furniture industry due to the application of a resin for internal use (UF), and to its aesthetic qualities, making the use of additional coverings unnecessary.

\section{CONCLUSION}

- The C. trichotoma and G. robusta species present wood density adequate to the lamination process.

- The use of P. taeda veneers in the core of the Cordia and Grevillea panels provides an increase in the values of superficial and total water absorption, and the Eucalyptus veneers reduce this property.

- The use of Pinus and Eucalyptus veneers in the plywood core, did not significantly affect the mechanical properties.

- The treatment that generally achieved the best physical-mechanical properties was that produced purely with C. trichotoma.

- The results indicated the technical viability of C. trichotoma and G. robusta for the manufacture of plywood panels in pure form, as well as the possibility of mixing these species with P. taeda and E. saligna in the core of the panel, to associate their aesthetic characteristics and mechanical strength.

- The potential applications of these panels are in the furniture industry and in products for use.

\section{ACKNOWLEDGEMENTS}

To Battistela Florestal and Hexion Resinas.

\section{SUBMISSION STATUS}

Received: 11 apr., 2017

Accepted: 05 aug., 2017

\section{CORRESPONDENCE TO}

\section{Rosilani Trianoski}

Departamento de Engenharia e Tecnologia

Florestal, Universidade Federal do

Paraná - UFPR, Av. Pref. Lothário Meissner, 632,

CEP 80210-170, Curitiba, PR, Brasil

email: rosilani@ufpr.br 


\section{REFERENCES}

Associação Brasileira da Indústria da Madeira Processada Mecanicamente - ABIMCI. Compensados de Pinus. Curitiba; 2002a. 20 p. (Catálogo Técnico; no. 1).

Associação Brasileira da Indústria da Madeira Processada Mecanicamente - ABIMCI. Compensados Tropicais. Curitiba; 2002b. 4 p. (Catálogo Técnico; n. 1).

Associação Brasileira da Indústria da Madeira Processada Mecanicamente - ABIMCI. Estudo Setorial 2005: ano base 2004. Curitiba; 2005. 52 p.

Associação Brasileira da Indústria da Madeira Processada Mecanicamente - ABIMCI. Estudo Setorial 2008: base 2007. Curitiba; 2008. 54 p.

Associação Brasileira da Indústria da Madeira Processada Mecanicamente - ABIMCI. Estudo Setorial 2013: base 2012. Curitiba; 2013. 127 p.

Associação Brasileira de Normas Técnicas - ABNT. NBR 9486. Chapas de madeira compensada: determinação da absorção de água. Rio de Janeiro; 1986.

Baldwin RF. Plywood manufacturing pratices. San Francisco: Miller Freeman; 1981. 326 p.

Bonduelle GM, Iwakiri S, Chies D, Martins D. Fatores que influenciam no rendimento em laminação de Pinus spp. Floresta e Ambiente 2006; 12(2): 35-41.

Bortoletto G. Produção de compensados com 11 espécies do gênero Eucalyptus, avaliação das suas propriedades físico-mecânicas e indicações para utilização. Scientia Forestalis 2003;63: 65-78.

Canto JL, Schneider PR. Crescimento da Grevillea robusta A. Cunn. na depressão central do Rio Grande do Sul, Brasil. Ciência Florestal 2004; 14(2): 29-35. http://dx.doi. org/10.5902/198050981804.

Carvalho PER. Louro-pardo. Boletim de Pesquisa Florestal, Colombo. Embrapa Florestas 1988; 17: 63-66.

Carvalho PER. Espécies arbóreas brasileiras. Vol. 2. Brasília: Embrapa Informação Tecnológica; Colombo: Embrapa Florestas; 2006. 628 p.

Comissão Panamericana de Normas Técnicas - COPANT. COPANT 458: maderas: selección y colección de muestras. Bolívia; 1972a.

Comissão Panamericana de Normas Técnicas - COPANT. COPANT 461: determinación del peso especifico aparente. Bolívia; $1972 b$.

European Committee for Standardization - CEN. European Standard EN 310: determination of modulus of elasticity in bending and of bending strength. Brussels; 2002a.

European Committee for Standardization - CEN. European Standard EN 314-2. Plywood - Bonding quality - Part 2: Requirements. Brussels; 2002b.
European Committee for Standardization - CEN. European Standard EN 314:1. Plywood - Bonding-quality - Part 1: Test methods. Brussels; 2004.

European Standard - EN. EN 322: determination of moisture content. Brussels; 2002a.

European Standard - EN. EN 323: determinação da massa volúmica. Brussels; 2002b.

Inoue MT, Martins EG. Variação sazonal da fotossíntese e clorofila em progênies de Grevillea robusta Cunn. Revista Ciências Exatas e Naturais 2006; 8(1): 113.

Iwakiri S. Painéis de madeira reconstituída. Curitiba: Fupef. 2005. 247 p.

Lamprecht H. Silvicultura nos trópicos: ecossistemas florestais e respectivas espécies arbóreas - possibilidades e métodos de aproveitamento sustentado. Rossdorf: TZVerl.- Ges. 1990. 343 p.

Lorenzi H. Árvores brasileiras: manual de identificação de plantas arbóreas nativas do Brasil. 2nd ed. São Paulo: Editora Plantarum; 1998. 368 p.

Machado SA, Figueiredo A Fo. Dendrometria. 2nd ed. Guarapuava: Unicentro; 2006. 316 p.

Martins EG, Sturion JA, Neves EJM. Produtividade de madeira e ganho genético de procedências de grevílea (Grevillea robusta Cunn.) na Região de Ponta Grossa, Paraná. Boletim de Pesquisa Florestal 2004; 48: 29-39.

Melo JE, Coradin VTR, Mendes JC. Classes de densidade para madeiras da Amazônia Brasileira. In: Anais do VI congresso florestal brasileiro, florestas e meio ambiente: conservação e produção, patrimônio social; 1990; Campos do Jordão. São Paulo: Sociedade Brasileira de Silvicultura: Sociedade Brasileira de Engenheiros Florestais; 1990. p. 695-699.

Siau JF. Transport processes in wood. New York; SpringerVerlag; 1984. 245 p. http://dx.doi.org/10.1007/978-3642-69213-0.

Stamm AJ, Loughborough WK. Thermodynamics of the swelling of wood. Journal of Physical Chemistry 1935; 39(1): 121-132. http://dx.doi.org/10.1021/j150361a009.

Trianoski R, Iwakiri S, Matos JLM, Higa AR, Braz RL. Avaliação das propriedades de painéis compensados de Melia azedarach produzidos com diferentes gramaturas e tempos de prensagem. Árvore 2015; 39(4): 759-768.

Tsoumis G. Science and technology of wood: structure, properties and utilization. New York: Van Nostrand Reinhold; 1991. 494 p.

Vieira MC, Brito EO, Gonçalves FG. Evolução econômica do painel compensado no Brasil e no mundo. Floresta e Ambiente 2012; 19(3): 277-285. http://dx.doi.org/10.4322/ floram.2012.033. 
Walker JCF. Primary wood processing: principles and practice. London: Chapman e Hall, 1993. 595 p. http:// dx.doi.org/10.1007/978-94-015-8110-3.

Wu Q. Application of Nelson's sorption isotherm to wood composites and overlays. Wood and Fiber Science 1999; 28(2): 227-239.
Zugman IC. Estrutura das indústrias e comércio de madeira compensada e laminada no Brasil e no mundo. In: Anais do I Seminário internacional sobre produtos sólidos de madeira de alta tecnologia; 1998; Belo Horizonte. Viçosa: SIF/UFV /DEF; 1998. p. 49-54. 